\title{
Assessing Recount Text Writing Ability Through Dicto-Comp of the Twelfth Grade Students of SMK Kharisma Mengwi in Academic Year 2015/2016
}

\section{Gede Wipradnyana}

\begin{abstract}
Writing is an activity which is used to express our ideas, emotions, thoughts and transfer them onto written form. In addition, teaching and assessment are inseparable in teaching and learning process. However, there are many problems confronted by the teachers in assessing the students' writing ability; furthermore, assessment has become a problem in teaching and learning process. The undertaking of the present study dealt with assessing recount text writing ability of the twelfth-grade students of SMK Kharisma Mengwi in academic year 2015/2016 through dicto-comp. The present study made use of ex post facto research design with descriptive analysis. The data required for the present study were gathered by means of administering dicto-comp to 40 samples of this study which were determined through random sampling technique with lottery system. The obtained data were analyzed using norm reference measure of five standard values. To sum up, these research findings revealed that there were $67.50 \%$ of the samples under study succeeded and the others $32.50 \%$ failed in writing recount text which was assessed by using dicto-comp.
\end{abstract}

Keywords: assessing, recount text writing ability and dicto-comp.

\section{Introduction}

Writing is an activity when someone selects and organizes their ideas into written statements to communicate with others. Most writing is the activity which is indirectly communication such as putting letters, symbols, numbers, or words on paper or computer screen. Flynn and Stainthorp (2006:55) state that writing has a communicative function. People write to communicate to others or to communicate to themselves. Furthermore, communication through writing should be clear and effective in order to avoid misunderstanding when someone expresses their thoughts and feelings to the readers. The writers must keep in mind the purpose for which they are writing and the audience they are addressing to choose the most appropriate words to convey ideas and information they have. Therefore, standard written forms must be learned to enable the writers expressing what they truly want to say to enhance the readers' comprehension. 
Brown (2001:336) states that writing is a process of thinking. It involves on how to express ideas into good writing and arranging ideas into statement. It is because writing is a process of putting ideas in their mind on a paper to transform them in words and become sentences by using structure and coherent organization. It indicates that writers are expected to explore their ideas and arrange them into good sentences and text that have meaning. The writers can use writing to record their thought, feeling, and personal thing as the evidence besides writing can be used for entertaining such as comics, novels, articles, newspapers, magazines and so on. In addition, writing is not only the activity of producing symbols of language in written form but also a means to deliver ideas.

Writing in English is not a simple matter because when someone writes something, they do not only demonstrate their competence in grammar of English, but also their knowledge communicative aspect of writing in English. When people start writing, they do not only write all their ideas. They need to convey and organize their ideas into a readable text that has some meanings. They have to think how to make their ideas can be understood clearly. Writing is no longer seen simply as a way of recording thought and feeling after the fact, but also as key means of generating and exploring new thought and ideas.

Writing nowadays has become part of language teaching as a system of communication rather than as an object of study. Kane (2000:3) states that writing is worth learning. Moreover, writing must be taught maximally by the teacher to the students. The ability to write either a native language or foreign language is widely recognized as an essential skill especially in education field. Therefore, teachers play important roles in increasing the students' writing ability. In writing, the students are not merely measured by the result at the end of teaching process. Harmer (2007:325) states that in writing, writer should focus on product of writing and also the process of writing. Both product and process of writing must be assessed and examined to achieve the authentic measurement and to obtain the evaluation of teaching process for the teacher.

Comparing the other three skills, writing is considered to be the most difficult skill to be mastered. It requires the writers' attention in expressing and developing ideas, using correct grammar, punctuation, spelling and vocabulary. Writing involves several components which 
have to be considered while a learner is writing. Zemach and Islam (2005: iv) state that writing is an important form of communication and the most difficult skill to be mastered in both first and second language. The learners understand the difficulty in writing; however, they still keep learning in order to ease them having interaction with each other.

Since writing is a complex process, there are some problems that can be found in process of writing. The students are not able to transfer and organize the ideas by using appropriate styles of writing and then express their thoughts clearly in English. The difficulty of writing is not only about developing the ideas but also how to make the ideas can be understood (Richards and Renandya, 2002:303). It means that when the students want to convey their ideas, they have to think how to make them become well organized to avoid confusion. Here, the English teacher's duties do not only give attention on problems that are faced by the students in writing but also evaluate and assess the student's ability.

Assessment can be a tool to measure students' ability and understanding. The result of the assessment can provide positive feedback to both teacher and students; in addition, it can measure whether the learning is successful or not.
Teachers can assess how the students' competency in writing to find the students' difficulties. Thus, the teachers can create good strategies to improve students' ability. Writing is seldom assessed like the other three skills. Commonly, the assessment of the students' writing is done only based on the topic or material. Ideally, the teachers are suggested to assess all parts and skills entailed in writing. However, most teachers assess students' writing by using conventional technique; moreover, sometimes they assess them subjectively.

Based on the observation that the researcher did, the teacher commonly did not use scoring rubric to assess the paragraph or a text that have been made by the students. The result when the students' writing was not assessed objectively was the students did not feel satisfied with their mark. Besides, writing assessment which was implemented was commonly monotonous and lack of stimulus in gaining students' interest in writing. The students were generally asked to write a text with a certain topic without any detail information. It made the students feel hard to do their writing; in addition, the result of their writing was commonly low.

The researcher is interested in focusing her research in assessing the 
students' writing ability especially recount text. Recount text is a text which retells past events or experience for the purpose of informing or entertaining. The researcher introduces a good test item that can be used to assess the students' writing which is dicto-comp. The main advantage of this test item is the preparation provides the learners with ideas, language items, and text organization so that they can focus on the skill aspect which is writing in the case of dicto-comp. This test item is also appropriate with the learners who are in intensive (controlled) writing level and it also can be used for any text types of writing. As a result, this kind of test item can be considered to be a good and appropriate instrument to assess students' writing ability.

The statements which have been stated above would clarify that English teacher must provide tests for their students to give them idea about the improvement of students in achieving learning objective; furthermore, one of the good tests is dicto-comp. Dicto-comp is a simple technique for guided compositions. Therefore, in accordance with the facts, the researcher is interested in assessing recount text writing ability of the twelfth-grade students of SMK Kharisma Mengwi in academic year 2015/2016 through dicto-comp.

\section{Research Method}

The present study, which dealt with assessing recount text writing ability of the twelfth-grade students of SMK Kharisma Mengwi in academic year 2015/2016 through dicto-comp, uses an ex post facto with descriptive analysis. This research design is defined as systematic empirical investigation in which the researcher does not have direct control or manipulation of the variable.

Ex post facto means from what is done afterwards. In the context of social and educational research, the phrase means after the fact or retrospectively and refers to those studies which investigate possible cause and effect relationship by observing an existing condition or state of affairs and searching back in time for plausible causal factors (Cohen et al., 2007:205). Then, it is a method of teasing out possible antecedents of events that have happened and cannot, therefore, be engineered or manipulated by the investigator.

Ary et al. (2010:332) state that the words ex post facto, derived from Latin means "after the fact", indicates that ex post facto research is conducted after the variation in the variable of interest has already been determined in the natural course of events. The statement showed that the ex post facto research design guides 
the researcher to analyse the dependent variable in the study what is caused by the independent variable. The dependent variable is known as the result of independent variable. It shows that the researcher cannot manipulate the independent variable in ex post facto research design.

Marczyk et al. (2005:209) define that descriptive analysis is frequently used to summarize a study sample prior to analysing a study's primary hypothesis. This provides information about the overall representativeness of the sample, as well as the information necessary for other researchers to replicate the study if they have desire. In other purely descriptive analysis, precise and comprehensive descriptions may be the primary focus of the study. In either case, the principal objective of descriptive statistics is to accurately describe distributions of certain variables within a specific data set.

The main characteristic of this method is that the researcher has no control over the variables; the researcher can only report what has happened or what is happening (Kothari, 2004:3). Most ex post facto research projects are used for descriptive studies in which the researcher seeks to measure such items as, for example, frequency of shopping, preferences of people, or similar data. Ex post facto studies also include attempts by researcher to discover causes even when they are not able to control the variables. This due to the fact that the manifestation of the variables has been previously and naturally taken place before the research was done. This means that in an ex post facto study, the researcher starts with observing a certain fact or phenomena and stepping back in her attempt to examine the attributable factors to existence of phenomena itself.

According to the explanation above, the present study used an ex post facto research design since the assessment of text writing ability becomes the prior variable to be taken in this research. In summary, the twelfth-grade students of SMK Kharisma Mengwi in academic year 2015/2016 have learnt writing through dissimilar quality and quantity of both formal and informal exposures in the target language and they have similar level of text writing ability. In ex post facto research, the researcher takes the effect for dependent variable and examines the data retrospectively to establish causes, relationship, and their meanings.

\section{Discussion}

\subsection{Writing Skill}

Writing is one skill of language, like an athletic skill which comes more naturally to some people. Writing is 
important to express ideas without sound. Besides, writing is both a physical and a mental act. It is the physical act of committing words or ideas to some medium, whether it is an object or a symbol or an email message. Writing is a productive skill that is used as a means of communication as well as speaking. Harmer (2004:255) adds that written text is different with speaking since it has issues of letter, word and text formation, manifested by handwriting, spelling, and layout and punctuation.

Writing is a symbol of representing language in visual form. Writing systems use sets of symbols to represent the sounds of speech and may also have symbols for such things as punctuation and numerals. Nunan (2003:88) states that writing is the process of thinking to invent ideas, thinking about how to express into good writing, and arranging the ideas into statement and paragraph clearly. It indicates that the students explore the ideas and make them into a good paragraph.

\subsection{Recount Text}

In writing, there are many forms of writing; in addition, one of them is texts. Text consists of several paragraphs and it must be unified and coherent. When people speak or write to communicate a message, they are constructing a text. Anderson and Anderson (1997:1) state that creating a text requires the writers to make choices about the words they use and how they put them together. The diction of the writers will depend on their purpose and their context. One form of texts which can be used to communicate is recount text.

The characteristics of recount text are using past tense, focusing on specific participants, and focusing on temporal sequence. It is also supported by Knapp and Watkins (2005:228) that recount most closely resemble the grammar of speech and basically has sequence events temporally, and also use a predominance of action verbs, and temporal connective. The generic structure of recount text consists of orientation, sequence of events, and reorientation. In addition, orientation provides the setting and introduces the participants in the text such as, who, where, and when the events take place. Events tell what happened and in what sequence. Reorientation tells us about optional closure of events, commonly the comment of the writers about the events.

Hyland (2003:20) states the purpose of recount text is to reconstruct past experiences by retelling events in original sequence. Furthermore, recount is used to retell for the purpose of informing and 
entertaining the audiences with the story or experience. One of types in recount text is personal recount. Personal recount is a recount which tells about a series of events that happened in the past that writer or the author got involved or acted in the event himself. The examples of personal recount are daily funny incidents and entries of a diary.

\subsection{Assessing Writing}

Assessing is giving score and feedback about students' work in order to know the achievement of students' ability. Brown (2004:4) states that assessment is a popular and sometimes misunderstood term in current educational practice. Assessment is an ongoing process that encompasses a much wider domain. Whenever students respond to a question, offers a comment, or tries out a new word or structure, the teacher subconsciously makes an assessment of students' performance. Moreover, assessment is a general term that includes the full range procedures used to gain information about student learning and the formation of value judgments concerning learning process.

Richards and Renandya (2002:346) argue that assessment involves the main of obtaining information about students' ability, knowledge, understanding, attainments. Moreover, assessment is the process of finding out who the students are, what their ability is, what they need to know, and how they perceive the learning will affect them. Assessment places the need of students at the center of the teacher's planning. Fulcher and Davidson (2007:27) write that the primary purpose of the assessment is to inform better teaching and more efficient learning that is done by the students at the end of the learning process.

\subsection{Dicto-Comp}

Dictation is one of the conventional controlled techniques used as a testing tool. It can be described as a technique where the learners receive some spoken input, hold this in memory for a short time, and write what they heard. This writing is affected by their skills at listening, command of the language and their ability to hold what they have heard in their memory. Richards and Renandya (2002:238) state that listening is assuming greater and greater importance in foreign language classroom. Harmer (2007:335) states that running dictation is the basic idea of a dictation has been altered so that it is the students who dictate to each other (rather than the teacher). It has a competitive element for the students; 
in addition, it is very active and often extremely enjoyable.

Brown (2004:225) states dictation is described as an assessment of the integration of listening and writing. One of many kinds of dictation is dicto-comp. Dicto-comp is a simple technique for guided compositions. This text type is the combination of two skills; those are listening and writing. Dicto-comp engages students in the learning difficulties and also helps to identify the requirements in grammatical patterns and structures. This text type emphasizes on how the students paraphrase or rewrite in their own words after careful listening. This is not only an effective classroom assessment method but it becomes an integrated part of the learning process within and beyond the classroom.

Zaragoza (2003:97) states that a variation of dictation called dictocomp is a wonderful relief from both the traditional dictation and the traditional composition. A text is read at normal speed, and may be repeated again and again, but always at normal speed. The students have to try to remember as accurately as possible what they have heard. The object is to reproduce the text as closely as possible to the original: this is the "dicto" part: the students can add their own words whenever necessary: this is the "comp" part. The object is not to write a resume or just to state the most important ideas; this is actually an exercise in note taking without the notes and provides practice in spelling, writing, shortterm memory and oral comprehension. Students are told not to take notes so that they can concentrate on key words or phrases of the text, on pauses and emphasis that might give clues to the meaning. They focus on the mental process of listening, without interference from the process of writing.

\section{Research Findings and Discussion}

In this section, the finding of the present research about recount text writing ability of the twelfthgrade students of SMK Kharisma Mengwi which was assessed through dicto-comp was discussed more detail. As what had been presented by the tabulation of the research data on the previous tables and figure, the finding of present research could be elaborated as follows:

The result of the data analysis by using norm-reference measurement of five standard values, as tabulated above clearly showed that there were $5.00 \%$ of the samples who achieved excellent achievement of recount text writing; $35.00 \%$, good achievement; $27.50 \%$, sufficient achievement; $27.50 \%$, insufficient achievement; and $5.00 \%$, poor 
achievement. Hence, these research findings revealed that there were $67.50 \%$ of the samples under study succeeded and the others $32.50 \%$ failed in writing recount text.

In writing recount text, the samples wrote the text tidily and mostly fulfilled the requirements in format such as the title was written and the position was centered. Mostly, the first line of each paragraph was written in indented position. The samples put a period appropriately after every sentence in their text. However, the samples wrote the words mostly in inappropriate ways. The samples simply wrote the words that they had heard based on the way the researcher pronounced them. As a result, most of the words were not logically understood because the spellings were not correct. Most of the samples wrote the capital letters incorrectly. They did not write the capital letter in each of the beginning of the sentence. Commas were put inappropriately by the samples. They did not put commas in the sentence which could be ended by commas. It could be said that format and punctuation and mechanics in writing recount text was good.

In this study, the recount text of the samples was commonly unified and quite coherent. They used appropriate transition signals such as, first, second, and third to make the text become unified. The events developed or discussed the main idea which was stated in the orientation. Furthermore, it made the text become unified. They wrote a personal recount text as the basic requirement of the research instrument. They wrote a personal recount text in the first person which was appropriate with the requirement of the test. However, there were some samples who did not use appropriate transition signals and correct linking verbs so that their recount text was hard to understand.

In writing the recount text, some of the samples' texts were begun with appropriate orientation and ended with appropriate reorientation. They stated the orientation which provided the setting, introduced the participants, and gave necessary background completely. They also wrote the reorientation which provided their personal comment or closing statement. The events were written in sequence appropriately. However, most of them did not write the events based on the keywords given. The students did not use the keywords provided appropriately. They used their own words; furthermore, it made the meaning of their text have a lot of differences with the original text. 
Furthermore, the findings of the present study which had showed sufficient writing achievement of the twelfth-grade students of SMK Kharisma Mengwi was carefully generalized to the population of the study. Moreover, it showed that dictocomp was an effective technique to assess the samples writing ability because it emphasized on comprehensibility. This technique could give some advantages for the students in which it could stimulate the students' creativity to do the test since they were provided the ideas, language items, and text organization so they can focus on making personal recount text writing.

In conclusion, there were $67.50 \%$ of the samples who could write a personal recount text by using dicto-comp. Besides, it showed that dicto-comp was an effective technique to assess the samples' writing ability because it emphasized on their mental process of listening and comprehension. This technique could give some advantages for the samples in which the samples felt stimulated to be creative to do the test since they were helped by the text and keywords given to make a good recount text based on its generic structure

\section{Conclusion}

The purpose of this study was to find out the degree of recount text writing of the twelfth-grade students of SMK Kharisma Mengwi in academic year 2015/2016 when it was assessed through dicto-comp. Moreover, the data were collected by means of administering the research instrument. Furthermore, the text was scored based on the five criteria: format, punctuation and mechanics, content, organization, and grammar and sentence structure. The result of the data computation was analyzed by using norm reference measure five standard values.

The data obtained for the present study were analyzed by using norm reference measurement with five standard values. If sufficient achievement (C) was considered as the minimum passing grade, it indicated that there were $67.50 \%$ of the samples under study succeeded and the others $32.50 \%$ failed in writing recount text which was assessed by administering dicto-comp.

The researcher could take a note that it should be careful in generalizing the findings to the whole population. This was due to the fact that research findings had rather limited validity and reliability. It was known that the use of ex post facto research design could be affected by some confounding independent variables so that they straightly affected validity and reliability of the findings. 


\section{REFERENCES}

Anderson, M. and Anderson, K. (1997). Text Types in English I. Southyourra: Macmillan.

Ary, D., Lucy C. J., and Chris S. (Ed). (2010). Introduction to Research in Education 8th Edition. Belmont, USA: Wadsworth.

Bailey, S. (2003). Academic Writing- A Practical Guide for Students. New York, NY: Nelson Thorries Ltd.

Brown, H. D. (2001). Teaching by Principles: An Interactive Approach to Language Pedagogy Second Edition. USA: San Francisco State University.

Brown, H. D. (2004). Language Assessment Principles and Classroom Practices. United States of America, USA: Pearson Education.

Coffin, C., Curry, M. J., Goodman, S., Hedwigs, A., Lillis, T. $\mathrm{M}$ and Swann, J. (2003). Teaching Academic Writing. London: Routledge.

Cohen, L., Lawrence M., and Keith M. (2007). Research Methods in Education: 6th Edition. New York: RoutledgeFalmer.
Connaway, S. and Ronald R. P. (2010). Basic Research Methods for Librarians. Colombia: Abe-elio.

Dawson, C. (2002). Practical Research Methods: A User-Friendly Guide to Mastering Research Techniques and Projects. United Kingdom: Oxford University Press.

Flynn, N. and Stainthorp, R. (2006). The Learning and Teaching of Reading and Writing. England: Whurr Publishers Limited.

Fulcher, G. and Davidson, F. (2007). Language Testing Assessment: An Advance Resource Book. New York: Routledge Applied Linguistics.

Graham, S. and Perin, D. (2007).Writing next: Effective Strategies to Improve Writing of Adolescents in Middle and High School- A Report to Carnegie Corporation of New York. Washington, DC: Alliance for Excellent Education

Harmer, J. (2004). How to Teach Writing. England: Pearson Longman. Harmer, J. (2007). The Practice of English Language Teaching. Cambridge: Pearson Longman. 
Hawthorne, S and Glenn, J. (2011).

Effective Practices in Teaching Writing in NZ Secondary School. Lyttelton: NZATE.

Hyland, K. (2003). Second Language Writing. Cambridge: University Press.

Kane, T. S. (2000). The Oxford Essential Guide to Writing. New York: Oxford University Press.

Knapp, P. and Watkins, M. (2005). Genre, Text, Grammar: Technologies for Teaching and Assessing Writing. Sydney: University of New South Wales Press Limited.

Kothari, C. R. (2004). Research Methodology: Method and Techniques (Second Revised Edition). New Delhi: New Age International (p) Ltd., Publishers.

Marczyk, G., DeMatteo, D., and Festinger, D. (2005). Essential of Research Design and Methodology. New Jersey: John Wiley and Sons, Inc.

Nunan, D. (2003). Practical English Language Teaching. New York: McGraw- Hill.
Oshima, A. and Hogue, A. (2006). Writing Academic English (Fourth Edition). New York: Longman.

Penayanti, P S. (2015). Assessing Writing Skill through Dicto-Comp of the Eighth Grade Students of SMPN 5 Mengwi in Academic Year 2014/2015. (Unpublished Thesis). Mahasaraswati Denpasar University, Denpasar.

Purnami, M A. (2014). Assessing Writing Skill through Dicto-Comp of the Twelfth Grade Students of SMAN 1 Susut in Academic Year 2013/2014. (Unpublished Thesis). Mahasaraswati Denpasar University, Denpasar.

Ramet, A. (2007).Creative Writing 7th Edition: How to Unlock Your Imagination, Develop Your Writing Skills and Get Published. United Kingdom: Oxford University Press.

Richards, J. C. and Renandya, W. A. (2002). Methodology in Language Teaching. Cambridge: Cambridge University Press.

Taylor, G. (2009). A Student's Writing Guide: How to Plan and Write Success Essay. New York, NY: Oxford University Press. 
Weigle, S. C. (2002). Assessing Writing.

Cambridge: Cambridge University

Press.

Wolff, J. (2007). Your Writing Coach: From Concept to Character, From Pitch to Publication. London: Nicholas Brealy Publishing.

Zaragoza, H. R. (2003). Dictadoviejaherramienta, nuevasaplicaciones. Venezuela: Universidad Metropolitana Distribuidor Universidad, Terrazasdel Avila.

Zemach, D. E., and Islam, C. (2005). Paragraph Writing: From Sentence to Paragraph. Macmillan: Macmillan Publisher Limited. 